\title{
PROTECTIVE ROLE OF POMEGRANATE JUICE BLENDED WITH WHEATGRASS AND LEMON EXTRACTS FOR RELIEVE CARBOHYDRATE INTOLERANCE
}

\author{
Hanaa G. Ishak ${ }^{1^{\star}}$, Ashoush ${ }^{1}$ I.S., El-Hofi ${ }^{1}$ M.A. \\ and Raafat ${ }^{2}$ S.S. \\ 1- Food Science Dept., Fac. of Agric., Ain Shams Univ., P.O. Box 68, Hadayek Shobra 11241, \\ Cairo, Egypt \\ 2- Cardiology Dept., Fac. of Medicine. Ain Shams Univ., Cairo, Egypt
}

"Corresponding author: hanaageorge01@gmail.com

Received 11 July, 2018

Accepted 3 September, 2018

\section{ABSTRACT}

Characteristics and protective effect of pomegranate juice (PJ), lemon juice (LJ), wheatgrass juice (WGJ) and their functional blends were evaluated. Total phenolics (TP), flavonoids (TF) content as well as free radical scavenging activity were determined. Meanwhile, total acidity, $\mathrm{pH}$ values were determined and the organoleptic attributes were evaluated. Also, the protective effect of functional blending juice against carbohydrate intolerance in patients was investigated by hydrogen breath test. The results revealed that the WGJ are low acidic in nature. While, the PJ and LJ showed high acidity which raised the total acidity in the functional blending juice. PJ had high content of total phenolics $17.45 \mathrm{mg} / \mathrm{ml}$ followed by 5.85 $\mathrm{mg} / \mathrm{ml}$ for functional blending juice. While, the LJ showed high acidity which raised the total acidity in the in the functional blending juice. PJ had high content of total phenolics $17.45 \mathrm{mg} / \mathrm{ml}$ followed by $13.25 \mathrm{mg} / \mathrm{ml}$ for functional blending juice. While, significant increase in the TF $22.15 \mathrm{mg} / \mathrm{ml}$ in the wheatgrass juice followed by functional blending juice $5.70 \mathrm{mg} / \mathrm{ml}$ significant increase in the TF $25.25 \mathrm{mg} / \mathrm{ml}$ in the functional blending juice followed by $22.15 \mathrm{mg} / \mathrm{ml}$ for wheatgrass juice. Whereas, the results showed that functional blending juice recorded the highest antioxidant activity, which revealed great free radical scavenging activity $98.16 \%$. Depending on sensory evaluation, the proportions of fourth blend WGJ: PJ: LJ in ratio 20:70:10 was most preferred for consumption by the panelists compared to other blending ratios.
After one month for patients group treated by functional blending juice at blinds ratio (WGJ 20: PJ 70: LJ 10), showed a significant decrease in the concentration of the hydrogen level in the exhalation air to reach a significant level of the control patients group, indicating the ability of the active compounds in functional blending juice to relieve the problems of carbohydrate intolerance. Accordingly, healthy promoting beverages can be produced by addition blending of pomegranate juice, lemon juice and wheatgrass juice.

Keywords: Wheatgrass, Pomegranate, Lemon, Antioxidant activity, Carbohydrate intolerance, Hydrogen breath test.

\section{INTRODUCTION}

Carbohydrates Intolerance is the most common non-immune-mediated adverse food reaction. The spread of carbohydrates intolerance has appeared to rise during the last few decades as a result of the increasing rate of carbohydrate consumption in food pattern Boettcher and Crowe (2013).

Carbohydrate malabsorption is primarily established by means of the hydrogen breath test. Some fermentable carbohydrates have been observed to growing rate the colonic hydrogen production. Although restriction of simple carbohydrates such as fructose or lactose, broader restriction of several short chain fermentable carbohydrates which namely the FODMAP (fermentable oligosaccharides, disaccharides, monosaccharides and polyols) in the diet. Therefore, reduce the highly intake 
of poorly absorbed, excessive fermentable shortchain carbohydrates and polyols (FODMAPS) to protective from carbohydrate intolerance (Gibson and Shepherd, 2005; Yao et al 2013).

Nowadays, consumption of healthy beverage is becoming more marketable among different age groups because of its thirst overcome, nutritional and therapeutical characteristics. Fruits and vegetables are perfect sources of bioactive compounds, and there are a huge number of polyphenolic compounds rich beverages, which base their marketing strategies on their powerful of antioxidant status. Meanwhile, numbers of cereal sprouts are used in beverage industry as health drink but wheat sprouts which namely wheatgrass is most favorable among them due to its strong health benefits. It is a rich source of the chlorophyll pigment, amino acids, minerals, vitamins and enzymes (Benarve, 2002).

Pomegranate juice has obtained commercial value in recent years in the food and health industries due to improve health gained. Pomegranates have high amount of polyphenols compounds and may be abundant source of compounds that had antiviral activity. The antioxidative stress power of pomegranate juice is more than other fruit juices. This antioxidant activity has been refer to the altitude of phenolic compounds content, including anthocyanin and ellagic acid (Gil et al 2000; Seeram et al 2008; Sundararajan et al 2010; Fawole and Opara, 2013).

Lemon juice is also a highly source of phytonutrients, including flavonoids, citric acid, ascorbic acid and potassium, which supplied plentiful of healthy promoting characteristics. Lemon juice is excessively used as an antioxidant natural replacer for the synthetic ascorbic or citric acids (E300 and E330, respectively). Furthermore, lemon juice could inhibit browning reactions and color deterioration of pomegranate juice (Martí et al 2001; Özkan, 2002; González-Molina, et al 2008).

Wheatgrass is extract of the cotyledons of the popular wheat plant (Triticum aestivum) which related to family Graminea (Mogra and Rathi 2013). Wheatgrass juice (also known as "green blood" and "plant super food") is extremely nutritious and in these days it is excessively used as a nutraceutical to protect human body from various health issues and enhancing the immune system and is considered as one of the best natural remedies for good health (Rana et al 2011; Shafi, 2015). It is also known as green blood due to their enhancing the red blood cells count (Grunewald 2009). It purifies the body, aids weight loss, and possesses antioxidant property (Siener et al 2006; Singh and Singh, 2012), scavenging free radicals (Kulkarni et al 2006) and detoxifying the colon walls (Das et al 2012).

The objective of the present study was to develop functional beverage from blending pomegranate, wheatgrass and lemon juice to get juice with highly nutritional and curative properties against intolerance of carbohydrate problems. The physicochemical properties and antioxidant activity of blended juice were also evaluated.

\section{MATERIALS AND METHODS}

\section{Materials}

Pomegranate (Punica granatum L.) and lemon (Citrus limon L.) fruits were purchased from local market. Whereas, Wheatgrass sprouts (Triticum aestivum) biomass was planted in horticultural farm, Horticultural Department, Faculty of Agriculture, Ain Shams University. The grass was harvested in the summer (November 2017), cut was made on the $10^{\text {th }}$ day after sowing, when the grass had reached a length of $16 \mathrm{~cm}$. While, ethanol, methanol, aluminum chloride and sodium carbonate were obtained from El-Gomhoreya Co., Cairo, Egypt. Also, 2, 2-diphenyl-2-picrylhydrazyl radical (DPPH) and Folin-Ciocalteus phenol reagent were purchased from Sigma-Aldrich Inc. (St Louis, MO, USA).

\section{Preparation of pomegranate juice and lemon juice}

Pomegranate and lemon fruits were washed by tap water and drained. Pomegranate fruits were manually cut-up and the outer leathery skin which encloses hundreds of fleshy sacs was removed. The juice that is located in the sacs was extracted using a domestic squeezer (Kenwood juicer, USA). While, lemon fruits were cut into half, squeezed and filtered. All juices obtained were stored under freezing conditions $\left(-20^{\circ} \mathrm{C}\right)$ until using and analyzed according to (Maskan, 2006).

\section{Preparation of Wheatgrass juice extract}

The wheatgrass (Triticum aestivum L.) was washed with tap water and extracted by cold extraction procedure with water $(50 \mathrm{~g}$ of fresh weight was used to prepare $100 \mathrm{ml}$ wheatgrass juice by crushing the leaves in water using Kenwood juicer, USA) according to the method described by (Mondal and Saxena, 2016). 


\section{Preparation of functional juice blends}

Formulated five different blends from juice samples were prepared freshly from individual juice in varying proportions from mixture of wheatgrass juice (WGJ): pomegranate juice (PJ): lemon juice (LJ) as follows: 50:40:10, 40:50:10, 30:60:10, 20:70:10 and the final prepared juice was $100 \%$ wheat grass juice (WGJ).

\section{Method of analysis}

\section{Physicochemical characteristics}

Total titratable acidity (TTA) and $\mathrm{pH}$ values were evaluated as quality indices. The $\mathrm{pH}$ values were measured using a $\mathrm{pH}$ meter (Mettler Toledo, Greifensee, Switzerland). Means of 3 replicates were reported for each treatment. TTA was determined potentiometrically by titrating $3.0 \mathrm{gm}$ for juice samples and their blinding using $0.1 \mathrm{M} \mathrm{NaOH}$ to the end point of $\mathrm{pH} 8.1$, TTA expressed as grams of citric acid per liter according to AOAC (2012).

\section{Determination of total phenolics content:}

The total phenolics content of the juice samples was determined colorimetrically, using the FolinCiocalteu method, as described by Singleton et al (1999). Aliquots of $0.5 \mathrm{ml}$ of the juice samples were added to $0.5 \mathrm{ml}$ of Folin reagent, followed by addition of $0.5 \mathrm{ml}$ of an aqueous $7.5 \%$ solution of sodium carbonate. The mixture was stirred and allowed to stand for $30 \mathrm{~min}$. The absorbance at $765 \mathrm{~nm}$ was measured, blank sample consisting of water and reagents was used as a reference. The results were expressed as milligrams of gallic acid equivalents per $\mathrm{ml}$ extract ( $\mathrm{mg} \mathrm{GAE} / \mathrm{ml}$ ) by reference to the gallic acid calibration curve.

\section{Determination of total flavonoids:}

The total flavonoids content was determined as described by Mohdaly et al (2012). A $100 \mu \mathrm{L}$ aliquot of $2 \% \mathrm{AlCl}_{3}$ ethanolic solution was added to $100 \mu \mathrm{L}$ of the juice samples and mixed well. After keeping for one $\mathrm{hr}$ at room temperature, the absorbance at $420 \mathrm{~nm}$ was measured. A yellow color indicates the presence of flavonoids. The total flavonoid contents were expressed as milligram quercetin equivalents.

\section{Assay the free-radical scavenging capacity:}

The ability of the extracts to scavenge DPPH free radicals was determined by the method described by Brand-Williams, et al (1995). Aliquots $0.1 \mathrm{ml}$ of juice samples was mixed with $2.9 \mathrm{ml}$ of $0.1 \mathrm{mM}$ DPPH in methanol. The control samples contained all reagents except the juice samples. The reaction mixture was shaken well and allowed to react for $20 \mathrm{~min}$ at room temperature. The remaining DPPH free radical was determined by absorbance measurement at $517 \mathrm{~nm}$ against methanol blanks. The percentage of scavenging effect was calculated from the decreased in absorbance against control according to the following equation:

$$
\begin{gathered}
\text { Scavenging activity } \%=\left[\left(\text { Abs }_{\text {control }}-\mathbf{A b}-\right.\right. \\
\left.\left.\mathbf{S}_{\text {sample }}\right) / \mathbf{A b s}_{\text {control }}\right] \times 100
\end{gathered}
$$

\section{Sensory evaluation of functional juice blends}

Ten semi trained panelists from the staff of Food Science Department Ain Shams University were asked to score the pomegranate based functional beverage in varying proportions through the sensory evaluation hedonic test questionnaire for their appearance, color, taste, flavor, consistency, aftertaste and overall acceptability giving numerical scores to each of their attributes from the scale of 0-9 ranging from "like extremely" to "dislike extremely" using a report sheet according to Pruthi and Singh (2014).

\section{Study Population}

This was a prospective observational pilot study which included patients referred to the cardiology clinic in the Cardiology Department Ain Shams University Hospital in the period from November 2017 to January 2018. Out of 95 patients referred to the clinic in the specified period of time, 11 patients suffering symptoms suggestive of carbohydrate intolerance were enrolled in the study. While, (32 patients were excluded as they didn't suffer any food related gastrointestinal tract symptoms, 33 patients were excluded as they suffered associating lung related disease preventing performance of hydrogen breath test while the rest of patients were not cooperative during performance of the test). The study populations were classified into two groups based on the hydrogen breath test performed: Group 1: included 11 patients with abnormal hydrogen breath test and receiving func- 
tional blending juice. While, Group 2: included 9 patients with normal hydrogen breath test (control group).

\section{Hydrogen breath test (HBT) procedure}

Hydrogen breath test was performed using (LactoFAN2, Leipzig, Germany) device that is used in diagnosis of malabsorption sugars. Breath test is performed after overnight fast. Before the test, subjects are asked to brush their teeth and rinse mouth with anti-septic mouth wash and tap water, to eliminate an early hydrogen peak due to action of oral bacteria on test sugars. At the start of the test, fasting breath hydrogen is estimated and taken as the basal breath hydrogen. Subsequently, the subject ingests a fixed amount of the test sugar (25 $\mathrm{g}$ lactose or $25 \mathrm{~g}$ fructose). All samples of breath are analyzed for hydrogen every 30 minutes for 3 hours. Special computer softwares are available to record values of the breath tests. Development of symptoms following ingestion of the substrate is also noted. Hydrogen breath test for diagnosis of carbohydrate malabsorption when rise in hydrogen by $20 \mathrm{ppm}$ above basal after carbohydrate ingestion is considered as positive carbohydrate HBT according to the methodolgy discriebed by Romagnuolo et al (2002).

\section{Statistical analysis}

All data were expressed as the mean \pm SE and they were analyzed statistically using the one-way analysis of variance ANOVA followed by Duncan's test. In all cases $p<0.05$ was used as the criterion of statistical significance by SAS program (SAS, 1996) according to the procedure reported by Steel et al (1997).

\section{RESULTS AND DISCUSSION}

\section{Physicochemical characteristics of different juices and their functional blends}

Tabulated data in Table (1) observed that the total acidity and $\mathrm{pH}$ value of wheatgrass juice are low acidic in nature. While, the lemon juice showed high acidity which raise the total acidity in the functional blending juice these results are in comparable with those obtained by Mondal and Saxena (2016).

Table 1. Physicochemical characteristics of different juices and their blends

\begin{tabular}{|l|c|c|}
\hline \multicolumn{1}{|c|}{ Juices } & $\mathbf{p H}$ & $\begin{array}{c}\text { Total acidity } \\
\text { (as citric acid) } \mathbf{g} / \mathbf{L}\end{array}$ \\
\hline Wheatgrass juice & $6.17 \pm 0.01^{\mathrm{a}}$ & $0.43 \pm 0.01^{\mathrm{d}}$ \\
Lemon juice & $2.10 \pm 0.06^{\mathrm{d}}$ & $5.45 \pm 0.0^{\mathrm{a}}$ \\
Pomegranate juice $^{\mathrm{a}}$ & $3.53 \pm 0.01^{\mathrm{b}}$ & $3.84 \pm 0.01^{\mathrm{c}}$ \\
Functional blending Juice $^{*}$ & $3.08 \pm 0.01^{\mathrm{c}}$ & $4.29 \pm 0.01^{\mathrm{a}}$ \\
\hline
\end{tabular}

$\mathrm{n}=3$, Means in the same column with the same letter are not significantly different $P<0.05$

*Wheat grass juice (WGJ) 20: pomegranate juice (PJ) 70: lemon juice (LJ) 10

Antioxidant status of different juices and their functional blends

The data presented in Table (2) showed that PJ was described by elevation content of total phenols $17.45 \mathrm{mg} / \mathrm{ml}$ followed by functional blending juice $13.25 \mathrm{mg} / \mathrm{ml}$. While, significant increase in the content of total flavonoids $22.15 \mathrm{mg} / \mathrm{ml}$ wheatgrass juice followed by $5.70 \mathrm{mg} / \mathrm{ml}$ in the functional blending juice prepared from a mixture of PJ: LJ: WGI with ratio70:10:20 in the functional blending juice prepared from a mixture of PJ : LJ : WGJ with ratio 20:70:10 followed by WGJ $22.15 \mathrm{mg} / \mathrm{ml}$.
Whereas, the results showed an increase in antioxidant activity in WGJ (94.53\%) followed by PJ (91.93\%) and LJ (51.46\%). While, the functional blending juice recorded the highest antioxidant activity, which revealed highly fight free radical activity $98.16 \%$. These results are in harmonization with those obtained by González-Molina et al (2009) reported that new designed beverages, based on PJ and LJ (75:25\%), provided a beverage with perfect sensory characteristics, promoted bioactive composition and highly antioxidant activity, good for the development of new healthy beverage. 
Table 2. Antioxidant status of different juices and their functional blends

\begin{tabular}{|l|c|c|c|}
\hline \multicolumn{1}{|c|}{ Juices } & $\begin{array}{c}\text { Total phenolics } \\
\mathbf{( m g / m l )} \text { as } \\
\text { gallic acid }\end{array}$ & $\begin{array}{c}\text { Total flavonoids } \\
(\mathbf{m g} / \mathbf{m l}) \text { as quercetin }\end{array}$ & $\begin{array}{c}\text { Scavenging activity } \\
\%\end{array}$ \\
\hline Wheatgrass juice & $3.33 \pm 0.05^{\mathrm{d}}$ & $22.15 \pm 0.57^{\mathrm{a}}$ & $94.53 \pm 0.66^{\mathrm{b}}$ \\
Lemon juice $_{\text {Pomegranate juice }}^{*}$ & $3.67 \pm 0.06^{\mathrm{c}}$ & $0.35 \pm 0.01^{\mathrm{d}}$ & $51.46 \pm 0.24^{\mathrm{e}}$ \\
Blending juice $^{*}$ & $17.45 \pm 0.05^{\mathrm{a}}$ & $1.76 \pm 0.04^{\mathrm{c}}$ & $91.93 \pm 0.58^{\mathrm{c}}$ \\
\hline
\end{tabular}

$\mathrm{n}=3$, Means in the same column with the same letter are not significantly different $P<0.05$

*Wheat grass juice (WGJ) 20: pomegranate juice (PJ) 70: lemon juice (LJ) 10

\section{Sensory evaluation of different juice blends}

Depending on sensory evaluation presented in Table (3) revealed that the proportion of fourth blends WGJ: PJ: LJ in ratio 20:70:10 was most preferred for consumption by the panelists in comparing to other blending ratios. While, WGJ (100 $\%$ ) were not much accepted by the panelists according to their taste, flavor and aftertaste.
Data no significant differences were noticed between juices blends in consistency. The differences in the sensory attributes could be referring to the various in raw materials and components of different juices. These results are in symmetrical with those of Kashudhan et al (2017) demonstrated that best sensory score was observed when wheatgrass juice is blended with different fruit juices.

Table 3. Sensory evaluation of different juice blends

\begin{tabular}{|l|c|c|c|c|c|}
\hline \multirow{2}{*}{ Attributes } & \multicolumn{5}{|c|}{ Juice blends $^{*}$} \\
\cline { 2 - 6 } & $\mathbf{1}$ & $\mathbf{2}$ & $\mathbf{3}$ & $\mathbf{4}$ & WGJ \\
\hline Appearance & $5.3 \pm 0.36^{\mathrm{b}}$ & $5.9 \pm 0.31^{\mathrm{ab}}$ & $6.0 \pm 0.39^{\mathrm{ab}}$ & $6.9 \pm 0.43^{\mathrm{a}}$ & $5.7 \pm 0.36^{\mathrm{b}}$ \\
Consistency & $6.0 \pm 0.29^{\mathrm{a}}$ & $6.6 \pm 0.26^{\mathrm{a}}$ & $6.6 \pm 0.33^{\mathrm{a}}$ & $6.1 \pm 0.48^{\mathrm{a}}$ & $5.9 \pm 0.34^{\mathrm{a}}$ \\
Taste & $5.0 \pm 0.44^{\mathrm{cd}}$ & $5.6 \pm 0.22^{\mathrm{bc}}$ & $6.6 \pm 0.26^{\mathrm{ab}}$ & $7.2 \pm 0.41^{\mathrm{a}}$ & $4.3 \pm 0.44^{\mathrm{d}}$ \\
Flavor & $5.0 \pm 0.29^{\mathrm{cd}}$ & $5.8 \pm 0.32^{\mathrm{bc}}$ & $6.5 \pm 0.22^{\mathrm{b}}$ & $8.0 \pm 0.33^{\mathrm{a}}$ & $4.4 \pm 0.40^{\mathrm{d}}$ \\
Aftertaste & $5.1 \pm 0.52^{\mathrm{ab}}$ & $5.3 \pm 0.68^{\mathrm{ab}}$ & $6.0 \pm 0.74^{\mathrm{a}}$ & $7.0 \pm 0.86^{\mathrm{a}}$ & $3.7 \pm 0.71^{\mathrm{b}}$ \\
Overall & $5.4 \pm 0.16^{\mathrm{c}}$ & $6.6 \pm 0.16^{\mathrm{ab}}$ & $6.9 \pm 0.27^{\mathrm{a}}$ & $7.5 \pm 0.37^{\mathrm{a}}$ & $5.8 \pm 0.44^{\mathrm{bc}}$ \\
\hline
\end{tabular}

$\mathrm{n}=10$, Means in the same raw with the same letter are not significantly different $P<0.05$

*1: wheat grass juice (WGJ) 50: pomegranate juice (PJ) 40: lemon juice (LJ) 10

2: wheat grass juice (WGJ) 40: pomegranate juice (PJ) 50: lemon juice (LJ) 10

3: wheat grass juice (WGJ) 30: pomegranate juice (PJ) 60: lemon juice (LJ) 10

4: wheat grass juice (WGJ) 20: pomegranate juice (PJ) 70: lemon juice (LJ) 10

WGJ: wheat grass juice (100\%)

Hydrogen breath test (HBT) for study population sample

The results in Table (4) revealed that the measurement of hydrogen level in the exhaled air in the patients sample of the study before and after the administration the functional juice at blinds ratio (WGJ 20: PJ 70: LJ 10) for one month showed a significant increase in the concentration of hydrogen level in exhaled air at the beginning of the experiment in the group one suffering from the symptom of carbohydrate intolerance compared to the second control negative group. The results of this test, after one month of the treatment group by functional blending juice, showed a significant decrease in the concentration of the hydrogen level in the exhalation air to reach a significant level of the control group, indicating the ability of the active compounds in functional blending juice to prevent the problems of carbohydrate intolerance. 
Table 4. Hydrogen breath test (HBT) for study population sample

\begin{tabular}{|c|c|c|}
\hline \multirow{2}{*}{ Variable } & \multicolumn{2}{|c|}{ HBT (ppm) } \\
\cline { 2 - 3 } & Before & After \\
\hline G1 & $87.18 \pm 22.55^{\mathrm{a}}$ & $14.55 \pm 2.72^{\mathrm{a}}$ \\
G2 & $8.43 \pm 1.83^{\mathrm{b}}$ & $8.43 \pm 1.83^{\mathrm{a}}$ \\
\hline
\end{tabular}

Means in the same column with the same letter are not significantly different $P<0.05$

G1: (11 participants) treated with functional juice at blinds ratio (WGJ 20: PJ 70: LJ 10)

G2: (9 participants) patients with normal hydrogen breath test (control negative group)

\section{CONCLUSION}

Based on the aforementioned data, we could concluded that the pomegranate juice with ratio from lemon and wheatgrass juices (WGJ 20 : PJ 70 : LJ 10) most preferred for consumption by the panelists as healthy promoting beverage exhibited a potential source for free radical scavenging activity and phytochemicals that have gastroprotective role by relieve the carbohydrate intolerance symptom.

\section{REFERENCES}

AOAC, 2012. Official Methods of Analysis of the Association of Official Analytical Chemistry. International, $19^{\text {th }}$ ed., Gaithersburg, Maryland, USA.

Benarve E. 2002. Wheat grass juice in the treatment of active distal ulcerative colitis: a randomized double-blind placebo-controlled trial. Scandinavian J. of Gastroenterology, 37(4), 444-449.

Boettcher E. and Crowe S.E. 2013. Dietary proteins and functional gastrointestinal disorders. Am. J. Gastroenterol., 108, 728-736.

Brand-Williams W., Cuvelier M.E. and Berset C. 1995. Use of a Free Radical Method to Evaluate Antioxidant Activity. Lebensm.-Wiss. u.Technol. LWT, 28, 25-30.

Das P., Mukhopadhy A., Mandal S., Chandra B., Mishra R., Mukherjee D., Mukhopadhyay S., Basak J. and Kar M. 2012. In vitro studies of iron chelation activity of purified active ingredients extracted from Triticum aestivum Linn. (Wheat Grass). Eur. J. Med. Plants 2, 113124.

Fawole O.A. and Opara U.L. 2013. Effects of maturity status on biochemical content, polyphenol composition and antioxidant capacity of pomegranate fruit arils (CV. Bhagwa). South African J. of Botany, 85, 23-31.

Gibson P.R. and Shepherd S.J. 2005. Personal view: food for thought Western lifestyle and susceptibility to Crohn's disease. The FODMAP hypothesis. Aliment Pharmacol. Ther., 21, 1399-1409.

Gil M.I., Tomas-Barberan F.A., Hess-Pierce B., Holcroft D.M. and Kader A.A. 2000. Antioxidant activity of pomegranate juice and its relationship with phenolic composition and processing. J. Agric. Food Chem., 48, 45814589.

González-Molina E., Moreno D.A. and GarcíaViguera C. 2008. Genotype and harvest time influence the phytochemical quality of Fino lemon juice (Citrus limon L.) for industrial use. J. of Agric. and Food Chem., 56(5), 16691675.

González-Molina E., Moreno D.A. and GarcíaViguera C. 2009. A new drink rich in healthy bioactives combining lemon and pomegranate juices. Food Chem. 115, 1364-1372.

Grunewald J. 2009. Novel botanical ingredients for beverages. Clin. Dermatol. 27, 210-216.

Kashudhan H., Dixit A. and Kumar K. 2017. Development of wheatgrass-pomegranate blended therapeutical juice using response surface methodology. J. of Food Processing and Preservation, 41(2), 1-12.

Kulkarni S., Tilak J., Acharya R., Rajurkar N., Devasagayam T. and Reddy A. 2006. Evaluation of the antioxidant activity of wheatgrass (Triticum aestivum L.) as a function of growth under different conditions. Phytother. Res. 20, 218-227.

Martí N., Pérez-Vicente A. and García-Viguera C. 2001. Influence of storage temperature and ascorbic acid addition on pomegranate juice. $\mathbf{J}$. of the Sci. of Food and Agric., 82(2), 217221.

Maskan M. 2006. Production of pomegranate (Punica granatum L.) juice concentrate by various heating methods: color degradation and kinetics. J. of Food Engineering, 72, 218-224.

Mogra R. and Rathi P. 2013. Health benefits of wheat grass - a wonder food. Int. J. Food Nutr. Sci., 2, 10-13.

Mohdaly A.A.A., Hassanien M.F.R., Mahmoud A., Sarhan M.A. and Smetanska I. 2012. Phenolics extracted from potato, sugar beet, and sesame processing by-products. International J. of Food Properties, 16, 1148-1168. 
Mondal A. and Saxena D. 2016. Development of barley grass juice and wheat grass juice as functional food with added other fruit juices and their organoleptic evaluation. American International J. of Research in Formal, Applied \& Natural Sci., 16(1), 17-22.

Özkan M. 2002. Degradation of anthocyanins in sour cherry and pomegranate juices by hydrogen peroxide in the presence of added ascorbic acid. Food Chem., 78(4), 499-504.

Pruthi R. and Singh P. 2014. Development and evaluation of antioxidant rich wheatgrass based nourishing beverage. International J. of Applied Health Sci., 1(1), 69-71.

Rana S., Kaur J. and Gandhi V. 2011. Living life the natural way - wheatgrass and health. J. Funct. Foods Health Dis. 1, 444-456.

Romagnuolo J., Schiller D. and Bailey R.J. 2002. Using breath tests wisely in a gastroenterology practice: an evidence-based review of indications and pitfalls in interpretation. Am. J. Gastroenterol. 97, 1113-1126

SAS, 1996. SAS/ Stat Users Guide: Statistics, System for Windows, version 4.10 (release 8.01 TS level 01M0), SAS Inst., Inc. Cary, North Carolina, USA

Seeram N.P., Aviram M., Zhang Y., Henning S.M., Feng L., Dreher M. and Heber D. 2008. Comparison of antioxidant potency of commonly consumed polyphenol-rich beverages in the United States. J. Agric. Food Chem., 56, 1415-1422.
Shafi S. 2015. Green blood therapy in modern medicine. International J. of Pharmaceutical, Chem. \& Biol. Sci., 5(3), 497-503.

Siener R., Honow R., Voss S., Seidler A. and Hesse A. 2006. Oxalate content of cereals and cereal products. J. Agric. Food Chem. 54, 3008-3011.

Singh A.K. and Singh K. 2012. Utilization of whey for the production of instant energy beverage by using response surface methodology. Adv. J. Food Sci. Technol. 4, 103-111

Singleton V.L., Orthofer R., and LamuelaRavento's R.M. 1999. Analysis of total phenols and other oxidation substrates and antioxidants by means of Folin-Ciocalteu reagent. Methods in Enzymology, 299, 152-178.

Steel R., Torrie J. and Dickey D. 1997. Principles and Procedures of Statistics: A Biometrical Approach. $3^{\text {rd }}$ Ed, McGraw-Hill, New York, NY, USA.

Sundararajan A, Ganapathy R., Huan L., Dunlap J.R., Webby R.J., Kotwal G.J. and Sangster M.Y. 2010. Influenza virus variation in susceptibility to inactivation by pomegranate polyphenols is determined by envelope glycoproteins. Antiviral Research, 88, 1-9.

Yao C.K., Gibson P.R. and Shepherd S.J. 2013. Design of clinical trials evaluating dietary interventions in patients with functional gastrointestinal disorders. Am. J. Gastroenterol., 108, 748-758. 


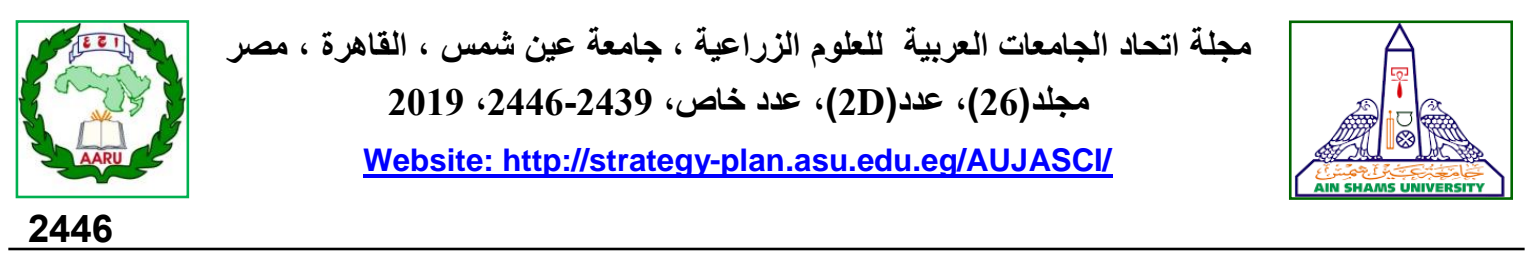

\section{الدور الوقائي لعصير الرمان المخلوط بمستخلصات مستنبت القمح والليمون لتخفيف عدم تحمل الكريوهيدرات}

[179]

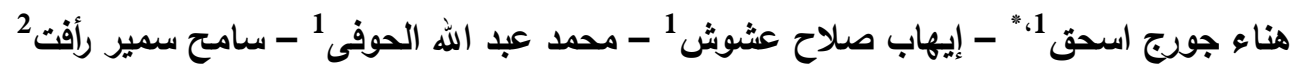

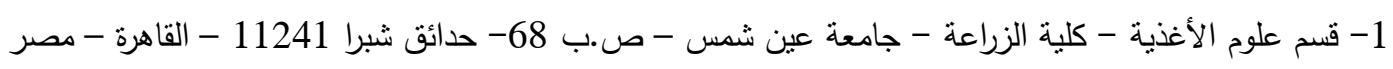

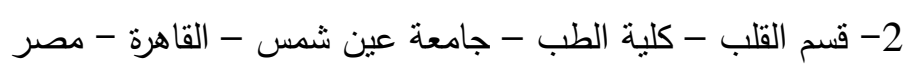

"Corresponding author: hanaageorge01@gmail.com

Received 11 July, 2018 Accepted 3 September, 2018

النتائج أن مزيج العصبر الوظيفي سجل أعلى نشاط

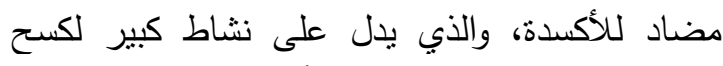

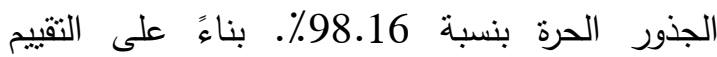

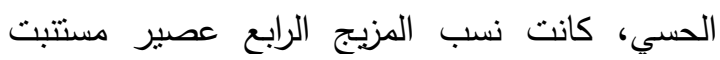

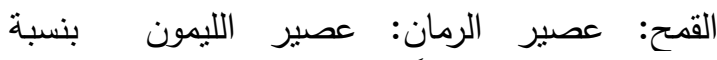

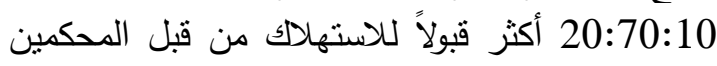

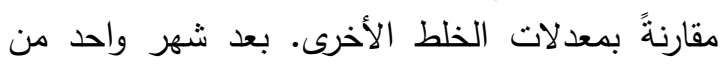

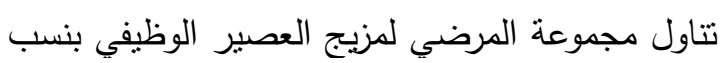

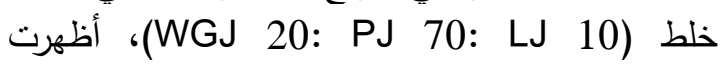
إنخفاض كبير في نركيز مستوى الهيدروجين في هواء

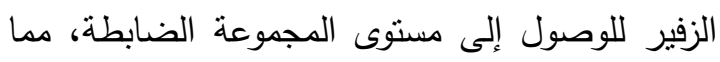
يشير إلى قدرة المركبات النشطة في مزيج العيترئ العصير الوظيفي لتخفيف مشاكل عدم تحمل الكربوهيدرات.

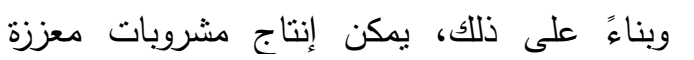
للصحة عن طريق إضافة خليط من عصير الرئر الرمان وعصير الليمون وعصير مستتبت القمح.

الكلمات الدالة: عصبر الرمان، مستتبت القمح،

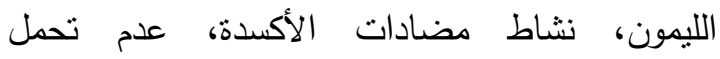
الكربوهيدرات، إختبار الهيدروجين في التتفس لإنس
تم تقييم التأثيرات الوقائية وخصائص عصير الرمان، عصير الليمون وعصير مسنتبت القمح لونح والمخاليط الوظيفية لهم. تم تقدير محتوى الفينولات

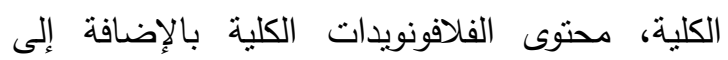

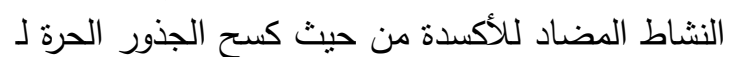

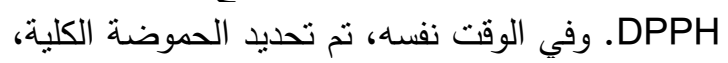

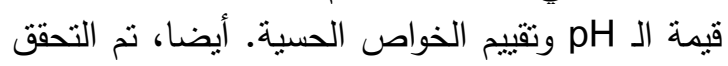

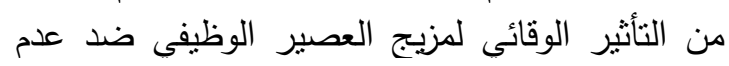

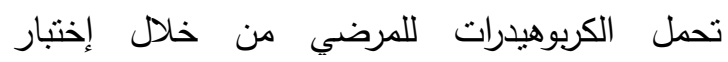
هيدروجين التنفس. أظهرت النتائج أن عصبر مستتبت القمح قليل

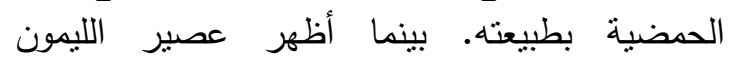

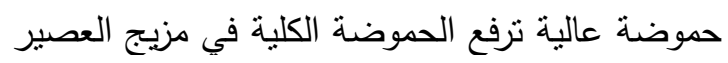

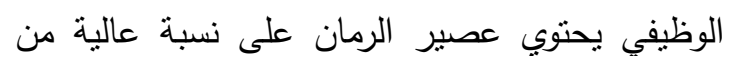

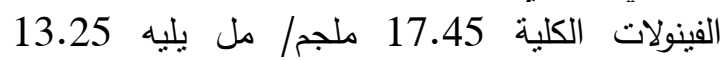
ملجم/مل لمزيج العصير الوظيفي. في حين أن يوجد زيادة كبيرة في محتوى الفلافونيدات الكلية 22.15 ملجم/ مل في عصير مسنتبت القمح تليها 5.70 ملجم/مل لمزيج العصبر الوظيفي. في حين أظهرت 